\title{
KEPUTUSAN INVESTASI DAN FINANCIAL CONSTRAINTS: STUDI EMPIRIS PADA BURSA EFEK INDONESIA
}

\author{
Riskin Hidayat ${ }^{1}$
}

\begin{abstract}
This research aims to test the sensitivity level of liquidity and invesment opportunity to invesment decision between non-financially constrained and financially constrained firms. Sample in this research is the firm of non finance which enlist in Indonesia Stock Exchange from period 2003 to 2007, obtained sample 136 firms with 680 observations. Result of research refer that liquidity and invesment opportunity have an influence on positive to invesment decision. Liquidity is more sensitive to invesment decision for financially constrained firms. Invesment opportunity is more sensitive to invesment decision for non financially constrained.
\end{abstract}

JEL Classification: E22, G32, 016.

Key words: Investment decision, liquidity, financially constraint.

1 (Penulis adalah Dosen STIE'YPPI' Rembang, alumni Magister Sains FEB-UGM. 


\section{PENDAHULUAN}

Keputusan investasi merupakan faktor penting dalam fungsi keuangan perusahaan. Fama (1978) menyatakan bahwa nilai perusahaan semata-mata ditentukan oleh keputusan investasi. Pendapat tersebut dapat diartikan bahwa keputusan investasi itu penting, karena untuk mencapai tujuan perusahaan yaitu memaksimumkan kemakmuran pemegang saham hanya akan dihasilkan melalui kegiatan investasi perusahaan.

Tujuan keputusan investasi adalah memperoleh tingkat keuntungan yang tinggi dengan tingkat risiko tertentu. Keuntungan yang tinggi disertai dengan risiko yang bisa dikelola, diharapkan akan menaikkan nilai perusahaan, yang berarti menaikkan kemakmuran pemegang saham. Dengan kata lain, bila dalam berinvestasi perusahaan mampu menghasilkan keuntungan dengan menggunakan sumber daya perusahaan secara efisien, maka perusahaan akan memperoleh kepercayaan dari calon investor untuk membeli sahamnya. Dengan demikian semakin tinggi keuntungan perusahaan semakin tinggi nilai perusahaan. Yang berarti semakin besar kemakmuran yang akan diterima oleh pemilik perusahaan.

Keputusan investasi meliputi investasi pada aktiva jangka pendek (aktiva lancar) dan aktiva jangka panjang (aktiva tetap). Aktiva jangka pendek biasanya didefinisikan sebagai aktiva dengan jangka waktu kurang dari satu tahun atau kurang dari satu siklus bisnis, dalam hal ini dana yang diinvestasikan pada aktiva jangka pendek diharapkan akan diterima kembali dalam waktu dekat atau kurang dari satu tahun dan diterima sekaligus. Tujuan perusahaan berinvestasi pada aktiva jangka pendek adalah untuk digunakan sebagai modal kerja atau operasional perusahaan. Contoh aktiva jangka pendek adalah persediaan, piutang, dan kas.

Sedangkan aktiva jangka panjang didefinisikan sebagai aktiva dengan jangka waktu lebih dari satu tahun, dalam hal ini dana yang ditanamkan pada aktiva jangka panjang akan diterima kembali dalam waktu lebih dari satu tahun dan kembalinya secara bertahap. Tujuan perusahaan berinvestasi pada aktiva jangka panjang adalah untuk meningkatkan nilai perusahaan.

Keputusan investasi dalam penelitian ini merupakan pengeluaran modal (capital expenditure) yaitu investasi pada aktiva tetap seperti tanah atau properti, bangunan, dan peralatan. Pengeluaran modal adalah dana yang dikeluarkan perusahaan dalam hal ini dengan pengeluaran tersebut perusahaan akan memperoleh manfaat lebih dari satu tahun. Motif dasar pengeluaran modal adalah untuk ekspansi, penggantian, atau memperbaharui aktiva tetap atau mencari manfaat yang mungkin less tangible dalam jangka panjang. Pengeluaran modal merupakan bagian dari penganggaran modal (capital budgeting). Menurut Riyanto (1997) penganggaran modal adalah keseluruhan proses perencanaan dan pengambilan keputusan mengenai pengeluaran dana dengan jangka waktu pengembalian dana melebihi satu tahun. 
Investasi modal merupakan salah satu aspek utama dalam keputusan investasi selain penentuan komposisi aktiva. Keputusan pengalokasian modal ke dalam usulan-usulan investasi yang manfaatnya akan direalisasikan di masa yang akan datang harus dipertimbangkan dengan cermat. Akibat ketidakpastian di masa yang akan datang, manfaat yang diperoleh menjadi tidak pasti, sehingga usulan investasi tersebut mengandung risiko. Konsekuensinya, usulan investasi harus dievaluasi dan dihubungkan dengan risiko dan hasil yang diharapkan.

Menurut Modigliani dan Miller (1958) bahwa pada kondisi pasar yang sempurna tidak ada hubungan antara keputusan investasi dan keputusan pendanaan. Menurut Arifin (2005), meskipun asumsi pasar sempurna dihilangkan, pemisahan antara keputusan investasi dan keputusan pendanaan masih terjadi meskipun ada sedikit modifikasi yaitu manajer harus menggunakan biaya modal rata-rata tertimbang sebagai discount rate. Bahkan ketika struktur modal telah menjadi relevan, baik karena faktor pajak atau karena faktor yang lain, masih saja tidak terjadi hubungan langsung antara investasi dan pendanaan. Yang ada adalah bahwa program investasi diputuskan dahulu baru kemudian diputuskan pendanaannya. Agar keputusan investasi benar-benar ditujukan untuk memaksimalkan nilai perusahaan, sehingga keputusan investasi seharusnya bersifat independen terhadap keputusan pendanaan.

Keputusan investasi tidak dapat diamati secara langsung oleh pihak luar. Beberapa studi yang dilakukan dalam hubungannya dengan keputusan investasi antara lain oleh Myers (1977) yang memperkenalkan set kesempatan investasi (investment opportunity set). Set kesempatan investasi memberi petunjuk yang lebih luas yang mana nilai perusahaan tergantung pada pengeluaran perusahaan di masa yang akan datang. Jadi prospek perusahaan dapat ditaksir dari kesempatan investasi. Set kesempatan investasi merupakan kombinasi antara aktiva yang dimiliki (assets in place) dan pilihan investasi di masa yang akan datang dengan net present value positif.

Menurut Gaver dan Gaver (1993), kesempatan investasi merupakan nilai perusahaan yang besarnya tergantung pada pengeluaran-pengeluaran yang ditetapkan manajemen di masa yang akan datang, dalam hal ini pada saat ini merupakan pilihan-pilihan investasi yang diharapkan akan menghasilkan keuntungan yang lebih besar. Pendapat ini sejalan dengan Smith dan Watts (1992) yang menyatakan bahwa set kesempatan investasi merupakan komponen nilai perusahaan yang merupakan hasil dari pilihan-pilihan untuk membuat investasi di masa yang datang. Menurut Kallapur dan Trombley (1999) bahwa kesempatan investasi perusahaan tidak dapat diobservasi untuk pihak-pihak di luar perusahaan sehingga diperlukan suatu proksi untuk melihatnya.

Menurut Modigliani dan Miller (1958) bahwa pada kondisi pasar yang sempurna tidak ada hubungan antara keputusan investasi dan keputusan pendanaan. Namun bukti empiris 
menunjukkan adanya keterkaitan antara keputusan investasi dan keputusan pendanaan, dalam hal ini ada keterkaitan antara tingkat likuiditas dan tingkat investasi pada banyak perusahaan. Bukti empiris Fazzari, Hubbard, dan Petersen (1988); Vogt (1994); Kaplan dan Zingales (1997); Cleary (1999); Moyen (2004); Almeida, Campello, dan Weisbach (2004) menunjukkan bahwa ada keterkaitan antara likuiditas dengan keputusan investasi pada perusahaan-perusahaan di Amerika Serikat. Hal yang sama juga ditemukan oleh Hoshi, Kashyap, dan Scharfstein (1991) di Jepang.

Bukti empiris di Indonesa ditunjukkan oleh Agung (2000), Kristianti (2003), dan Hermeindito (2004) yang menemukan bahwa likuiditas berhubungan positif dengan keputusan investasi. Sebaliknya Prasetyantoko (2007) dalam penelitiannya menunjukkan bahwa likuiditas berhubungan negatif terhadap keputusan investasi.

Dari hasil temuan empiris di atas, menunjukkan bahwa terdapat perbedaan antara teori yang menyatakan bahwa keputusan investasi dan keputusan pendanaan adalah independen dengan praktek yang dilakukan oleh perusahaan. Selain itu, hasil penelitian Fazzari, Hubbard, dan Petersen (1988); Vogt (1994); Hoshi, Kashyap, dan Scharfstein (1991); Hermeindito (2004) menunjukkan adanya perbedaan temuan sensitivitas keputusan investasi perusahaan dengan likuiditas ketika dimoderasi oleh financial constraints (hambatan finansial) dengan hasil penelitian Kaplan dan Zingales (1997); Cleary (1999); Kristianti (2003).

Penelitian Fazzari, Hubbard, dan Petersen (1988); Vogt (1994); Hoshi, Kashyap, dan Scharfstein (1991); Hermeindito (2004) menunjukkan bahwa keputusan investasi perusahaan lebih sensitif terhadap likuiditas pada perusahaan financially constrained selanjutnya disingkat FC, dibandingkan perusahaan non financially constrained selanjutnya disingkat NFC. Sebaliknya, Kaplan dan Zingales (1997); Cleary (1999); Kristianti (2003) menemukan bahwa keputusan investasi perusahaan lebih sensitif terhadap likuiditas pada perusahaan NFC dibandingkan perusahaan FC.

Adanya pertentangan bukti empiris antara Fazzari, Hubbard, dan Petersen (1988) yang didukung oleh Vogt (1994); Hoshi, Kashyap, dan Scharfstein (1991); Hermeindito (2004) dengan hasil penelitian empiris Kaplan dan Zingales (1997) yang didukung oleh Cleary (1999) dan Kristianti (2003), maka penelitian ini akan meneliti lebih lanjut faktor yang membedakan dua bukti yang bertentangan tersebut, yaitu dengan menggunakan variabel FC dan NFC sebagai pemoderasi.

Financial constraints adalah keterbatasan perusahaan dalam mendapatkan modal dari sumber-sumber pendanaan yang tersedia untuk berinvestasi. Kaplan dan Zingales (1997) menyatakan bahwa financial constraints terjadi bila perusahaan menghadapi perbedaan antara 
biaya modal dari sumber pendanaan internal dan biaya modal dari sumber pendanaan eksternal.

Berdasarkan uraian di atas dan hasil penelitian empiris, maka penelitian ini bertujuan untuk menguji tingkat pengaruh likuiditas dan kesempatan investasi terhadap keputusan investasi pada perusahaan FC dan NFC. Perusahaan FC yaitu perusahaan yang memiliki kendala keuangan dalam melakukan investasi, sedangkan perusahaan NFC yaitu perusahaan yang tidak memiliki kendala keuangan dalam melakukan investasi.

Keputusan investasi perusahaan sangat dipengaruhi oleh kesempatan investasi, karena semakin besar kesempatan investasi yang menguntungkan maka investasi yang dilakukan semakin besar, dalam hal ini manajer berusaha mengambil peluang-peluang tersebut untuk memaksimalkan kesejahteraan pemegang saham. Bila terdapat kesempatan investasi yang menguntungkan, maka perusahaan NFC akan dengan mudah mengambil kesempatan investasi tersebut untuk berinvestasi. Hal ini disebabkan perusahaan NFC mempunyai akses yang lebih mudah ke pasar modal, sehingga dapat dengan mudah menyesuaikan finansialnya untuk investasi yang menunjukkan fleksibelitas finansial yang lebih besar, dengan kata lain perusahaan NFC menunjukkan nilai perusahaan yang tinggi (Bhaddari, 1988; Chan dan Chen, 1991; Fama dan French, 1992). Perusahaan NFC juga cenderung sudah lama, lebih besar, lebih dewasa, dan lebih mengetahui pasar. Hal ini berarti bahwa dengan kondisi perusahaan yang telah mapan, maka perusahaan NFC dalam melakukan investasi cenderung sensitif terhadap kesempatan investasi.

Berdasarkan bukti empiris Fazzari, Hubbard, dan Petersen (1988); Vogt (1994); Kaplan dan Zingales (1997); Cleary (1999); Moyen (2004); Almeida, Campello, dan Weisbach (2004); Hoshi, Kashyap, dan Scharfstein (1991); Agung (2000), Kristianti (2003), Hermeindito (2004); Prasetyantoko (2007), keputusan investasi perusahaan juga dapat mempertimbangkan ketersediaan sumber pendanaan internal yaitu aliran kas. Keputusan investasi yang dibuat perusahaan dipengaruhi oleh kemampuan perusahaan menghasilkan kas yang dapat memenuhi kebutuhan jangka panjang maupun jangka pendek atau yang disebut likuiditas perusahaan. Perusahaan harus menjaga likuiditas agar tidak terganggu, sehingga tidak menganggu kelancaran aktivitas perusahaan untuk melakukan investasi dan tidak kehilangan kepercayaan diri dari pihak luar.

Perusahaan FC cenderung menggunakan likuiditas untuk mendanai investasi. Hal ini karena perusahaan FC memiliki keterbatasan akses terhadap pasar modal dan relatif lebih kecil, yang menunjukkan keterbatasan finansial sehingga akan sulit bagi perusahaan mengambil kesempatan investasi yang menguntungkan untuk investasi. Dengan kata lain bahwa perusahaan FC mempunyai nilai perusahaan yang rendah. 
Menurut Fazzari, Hubbard, dan Petersen (1988) bahwa adanya asimetri informasi pada pendanaan eksternal (hutang) akan menimbulkan biaya pendanaan eksternal lebih mahal dari pada pendanaan internal, yang berakibat perusahaan $F C$ kurang memiliki akses ke pendanaan eksternal. Dengan keterbatasan tersebut, maka keputusan investasi perusahaan FC cenderung lebih sensitif terhadap likuiditas.

Sebagaimana telah disebutkan di atas, bahwa terdapat perbedaan hasil penelitian tentang tingkat pengaruh likuiditas terhadap keputusan investasi ketika dimoderasi oleh financial constrains, khususnya penelitian yang dilakukan oleh Kristianti (2003) dan Hermeindito (2004) di Indonesia. Penelitian Kristianti (2003) mendukung temuan Kaplan dan Zingales (1997) dan Cleary (1999) yang menunjukkan bahwa likuiditas lebih berpengaruh terhadap keputusan investasi pada perusahaan NFC dibanding perusahaan FC.

Sebaliknya, hasil penelitian Hermeindito (2004) mendukung penelitian Fazzari, Hubbard, dan Petersen (1988); Vogt (1994); Hoshi, Kashyap, dan Scharfstein (1991) yang menunjukkan bahwa likuiditas lebih berpengaruh terhadap keputusan investasi pada perusahaan FC dibanding perusahaan NFC. Berdasarkan perbedaan hasil penelitian tersebut, maka penelitian ini bermaksud untuk merekonsiliasi tingkat pengaruh likuiditas dan kesempatan investasi terhadap keputusan investasi dengan memasukkan variabel FC dan NFC sebagai pemoderasi.

Bagian kedua dari paper ini akan mengulas teori dan penurunan 4 hipotesis yang diuji dalam paper ini, bagian ketiga membahas metodologi yang digunakan dan bagian keempat menguraikan hasil estimasi dan analisis. Kesimpulan, implikasi dan saran akan menjadi penutup.

\section{TEORI}

Terdapat 3 aspek yang menjadi fokus analisis sebagai faktor yang mempengaruhi keputusan investasi. Tiga aspek tersebut adalah: (i) aspek likuiditas, (ii) kesempatan investasi, dan (iii) aspek financial constraint. Menurut Modigliani dan Miller (1958) bahwa pada kondisi pasar yang sempurna tidak ada hubungan antara keputusan investasi dan keputusan pendanaan. Namun bukti empiris menunjukkan adanya interdependensi antara keputusan investasi dan keputusan pendanaan, dalam hal ini ada keterkaitan antara tingkat likuiditas dan tingkat investasi pada banyak perusahaan.

Keputusan investasi yang dibuat perusahaan dipengaruhi oleh kemampuan perusahaan menghasilkan kas yang dapat memenuhi kebutuhan jangka panjang maupun jangka pendek atau yang disebut likuiditas perusahaan. Perusahaan harus menjaga likuiditas agar tidak terganggu, sehingga tidak menganggu kelancaran aktivitas perusahaan untuk melakukan investasi dan tidak kehilangan kepercayaan diri dari pihak luar. 
Likuiditas merupakan kemampuan perusahaan untuk memenuhi kewajibannya terutama kewajiban jangka pendek (Hanafi dan Halim, 2005). Menurut Riyanto (1997) perusahaan yang likuid adalah perusahaan yang memiliki kekuatan sedemikian besarnya sehingga mampu memenuhi segala kewajiban finansialnya yang segera harus dipenuhi, kemampuan membayar ini berhubungan dengan penyelenggaraan proses produksi.

Menurut Kaplan dan Zingales (1997), likuiditas merupakan kemampuan perusahaan untuk menghasilkan kas dalam memenuhi kebutuhan perusahaan baik jangka panjang maupun jangka pendek. Pengertian tersebut secara eksplisit menunjukkan apakah dengan kas yang tersedia perusahaan mengalami kesulitan untuk mendanai investasinya atau tidak. Perusahaan dikatakan tidak mengalami kesulitan dalam mendanai investasinya apabila perusahaan mampu menghasilkan kas dalam membiayai investasi.

Dalam penelitian ini likuiditas diproksikan dengan aliran kas (cash flow). Aliran kas terdiri dari aliran kas masuk dan aliran kas keluar. Aliran kas keluar biasanya digunakan untuk melakukan investasi baru, sedangkan aliran kas masuk merupakan hasil dari investasi tersebut. Menurut Brigham dan Ehrhardt (2005), laporan aliran kas merupakan laporan yang menjelaskan dampak aktivitas operasi, investasi, dan pendanaan perusahaan terhadap aliran kas selama satu periode akuntansi.

Geczy, Minton, dan Schrand (1997) menyatakan bahwa aliran kas perusahaan dengan level volatilitas tinggi memiliki pengeluaran, biaya riset dan pengembangan, serta biaya iklan lebih rendah. Hal tersebut berarti bahwa adanya perbedaan level investasi akan membuat volatilitas yang berbeda, tergantung pada tujuan investasi perusahaan. Biasanya perusahaan tidak menggunakan hutang atau pasar ekuitas agar volatilitas aliran kas tidak tajam, karena biaya masuk ke pasar modal juga berhubungan dengan volatilitas aliran kas perusahaan.

Penelitian Fazzari, Hubbard, dan Petersen (1988); Vogt (1994); Kaplan dan Zingales (1997); Cleary (1999); Moyen (2004); Almeida, Campello, dan Weisbach (2004) menunjukkan bahwa ada keterkaitan antara likuiditas dengan keputusan investasi pada perusahaan-perusahaan di Amerika Serikat. Hal yang sama juga ditemukan oleh Hoshi, Kashyap, dan Scharfstein (1991) di Jepang.

Bukti empiris di Indonesa ditunjukkan oleh Agung (2000), Kristianti (2003), dan Hermeindito (2004) yang menemukan bahwa likuiditas berhubungan positif dengan keputusan investasi. Sebaliknya Prasetyantoko (2007) dalam penelitiannya menunjukkan bahwa likuiditas berhubungan negatif terhadap keputusan investasi. Berdasarkan uraian tersebut, maka hipotesis pertama yang diuji dalam paper ini adalah bahwa ILikuiditas berpengaruh positif terhadap keputusan investasi. 
Myers (1977) menyatakan bahwa kesempatan investasi merupakan kombinasi antara aktiva yang dimiliki dan pilihan investasi di masa yang akan datang dengan NPV positif. Gabungan aset milik perusahaan (assets in place) dengan kesempatan investasi akan berpengaruh pada struktur modal. Gaver dan Gaver (1993) menyatakan bahwa kesempatan investasi merupakan nilai perusahaan yang besarnya tergantung pada pengeluaran-pengeluaran yang ditetapkan manajemen di masa yang akan datang dalam hal ini pilihan-pilihan investasi yang diharapkan akan menghasilkan return yang lebih besar.

Menurut Chung dan Charoenwong (1991) bahwa esensi pertumbuhan bagi suatu perusahaan adalah adanya kesempatan investasi yang menghasilkan keuntungan. Jika terdapat kesempatan investasi yang menguntungkan, maka manajer berusaha mengambil peluangpeluang tersebut untuk memaksimalkan kesejahteraan pemegang saham. Karena semakin besar kesempatan investasi yang menguntungkan, maka investasi yang dilakukan akan semakin besar.

Dalam penelitian ini, proksi dari kesempatan investasi adalah rasio book to market. Rasio book to market adalah rasio nilai buku terhadap harga saham. Perusahaan yang memiliki rasio book to market yang tinggi mengindikasikan bahwa siklus tumbuh perusahaan pada masa yang akan datang bagus, sehingga akan memiliki kesempatan investasi yang tinggi, dengan demikian perusahaan akan mudah untuk melakukan investasi karena investor akan tertarik untuk membeli saham perusahaan.

Penelitian Fazzari, Hubbard, dan Petersen (1988); Vogt (1994); Kaplan dan Zingales (1997); Cleary (1999); Almeida, Campello, dan Weisbach (2004); Prasetyantoko (2007) menunjukkan bahwa kesempatan investasi berpengaruh positif terhadap keputusan investasi. Sebaliknya penelitian Moyen (2004) menunjukkan bahwa kesempatan investasi berpengaruh negatif terhadap keputusan investasi. Dengan demikian, maka hipotesis kedua yang diajukan pada penelitian ini adalah kesempatan investasi berpengaruh positif terhadap keputusan investasi.

Menurut Myers dan Majluf (1984) bahwa proporsi sentral dari modal berbasis asimetri informasi sangat mahal. Lebih lanjut Myers dan Majluf (1984) berpendapat bahwa dividen bersifat sticky, berarti peningkatan dividen dilakukan bila manajer merasa yakin dapat menyediakan aliran kas permanen (baik internal maupun eksternal) yang cukup pada masa yang akan datang. Penurunan dividen dilakukan bila perusahaan menghadapi financial constraints yang tinggi, secara eksternal merasa tidak dapat mempertahankan aliran kas permanen yang cukup untuk membiayai investasi. Oleh karena itu perusahaan FC lebih mengandalkan sumber pendanaan internal dari pada eksternal, perusahaan cenderung menyesuaikan dividen berdasarkan peluang investasi yang tersedia. 
Menurut Jansen dan Meckling (1976) bahwa manajer lebih senang menggunakan modal internal untuk membiayai investasi karena modal internal dapat mengurangi keterlibatan pengawasan dari pemegang saham atau pihak eksternal terhadap keputusan investasi yang dibuat oleh manajer. Fazzari, Hubbard, dan Petersen (1988) menyatakan bahwa perusahaan FC cenderung lebih sensitif terhadap pendanaan internal (likuiditas) dalam melakukan investasi. Kecenderungan tersebut disebabkan karena adanya asimetri informasi pada pendanaan eksternal, sehingga pendanaan eksternal (hutang) lebih mahal dari pada pendanaan internal yang berakibat perusahaan FC kurang memiliki akses ke sumber pendanaan eksternal.

Penelitian Fazzari, Hubbart, dan Petersen (1988); Hoshi, Kashyap, dan Scharfstein (1991); Schaller (1993); Almeida, Campello, dan Weisbach (2004) menunjukkan bahwa keputusan investasi perusahaan FC lebih sensitif terhadap likuiditas dibandingkan perusahaan NFC. Sebaliknya, penelitian Kaplan dan Zingales (1997) dan Cleary (1999) menunjukkan bahwa investasi dari perusahaan NFC lebih sensitif terhadap likuiditas dibandingkan investasi dari perusahaan FC.

Penelitian Moyen (2004) menemukan bahwa ketika menggunakan klasifikasi berdasarkan dividend payout, cash flow, dan kriteria Fazari, Hubbard, dan Petersen perusahaan FC lebih sensitif terhadap likuiditas dibanding perusahaan NFC dalam berinvestasi. Sebaliknya ketika menggunakan Indeks Cleary dan kriteria Kapalan dan Zingales ditemukan bahwa perusahaan NFC lebih sensitif terhadap cash flow dibanding perusahaan FC dalam berinvestasi.

Bukti empiris di Indonesia ditujukkan oleh Agung (2000) yang menemukan adanya hubungan positif likuiditas dengan keputusan investasi. Kristianti (2002) dalam penelitiannya menunjukkan bahwa likuiditas lebih sensitif terhadap keputusan investasi pada perusahaan NFC dibanding perusahaan FC. Sebaliknya, Hermeindito (2004) menemukan bahwa likuiditas lebih sensitif terhadap keputusan investasi pada perusahaan FC dibanding perusahaan NFC. Prasetyantoko (2007) juga menunjukkan bahwa likuiditas berpengaruh negatif pada investasi. Mengacu pada uraian ini, maka hipotesis ketiga yang diuji adalah bahwa likuiditas lebih berpengaruh terhadap keputusan investasi pada perusahaan financially constrained dibanding perusahaan non financially constrained.

Menurut Jensen dan Meckling (1976) kebijakan dividen dan kesempatan investasi merupakan mekanisme kontrol manajemen yang dapat bersifat substitusi lebih tergantung penerapannya dari ketersediaan sumber pendanaan internal dari pada sumber pendanaan eksternal melalui kesempatan investasi. Perusahaan yang memiliki sumber pendanaan internal tinggi dikontrol melalui pembayaran dividen tinggi sehingga perusahaan ini dapat diklasifikasikan sebagai NFC. Dengan demikian perusahaan NFC dapat dengan mudah menyesuaikan sumber pendanaan untuk investasi yang menunjukkan fleksibelitas finansial yang lebih besar dan 
cenderung mempunyai akses lebih mudah ke pasar modal eksternal, dengan kata lain perusahaan NFC menunjukkan nilai perusahaan yang tinggi (Bhaddari, 1988; Chan dan Chen, 1991; Fama dan French, 1992).

Prasetyantoko (2007) dalam penelitiannya menunjukkan bahwa kesempatan investasi berpengaruh positif terhadap keputusan investasi. Kaplan dan Zingales (1997); Cleary (1999) menemukan bahwa keputusan investasi perusahaan NFC lebih sensitif pada kesempatan investasi dibandingkan pada perusahaan FC. Sebaliknya, Moyen (2004) menemukan bahwa secara umum kesempatan investasi berpengaruh negatif terhadap investasi pada perusahaan NFC dan FC. Almeida, Campello, dan Weisbach (2004) menunjukkan bahwa kesempatan investasi lebih sensitif terhadap keputusan investasi pada perusahaan FC dibanding perusahaan NFC. Dengan dasar tersebut, maka hipotesa bahwa kesempatan investasi lebih berpengaruh terhadap keputusan investasi pada perusahaan non financially constrained dibanding perusahaan financially constrained, merupakan hipotesa keempat yang diuji dalam paper ini.

\section{METODOLOGI}

\section{III.1. Data dan Konseptualisasi Variabel}

Data yang diperlukan pada penelitian ini adalah laporan keuangan perusahaan dari tahun 2003 - 2007. Populasi dalam penelitian ini adalah perusahaan publik yang tercatat di Bursa Efek Indonesia (BEI) dan sampel penelitian ini adalah perusahaan publik non keuangan yang tercatat di BEI. Data diperoleh dari BEI dan ICMD (Indonesia Capital Market Directory). Kriteria pengambilan sampel pada penelitian ini adalah perusahaan non keuangan yang terdaftar di BEl serta mempublikasikan laporan keuangannya dari tahun 2003 - 2007 secara konsisten.

Variabel independen pada penelitian ini adalah likuiditas yang diproksikan dengan cash flow (aliran kas) dan kesempatan investasi yang diproksikan dengan book to market. Untuk mengukur cash flow dan book to market sebagai berikut:

$$
\text { Cash flow }=\frac{\begin{array}{c}
\text { netincome }+ \text { penyusutan dan/atau amortisasi }+ \\
\text { selisih pembayaran pajak yang ditanggulkan }
\end{array}}{\text { aktiva tetap }}
$$

Yang dimaksud aktiva tetap dalam penelitian ini adalah tanah, gedung, peralatan, dan perlengkapan. Cash flow dibagi dengan aktiva tetap untuk mengkontrol efek perbedaan skala perusahaan.

$$
\text { Book to market }=\frac{\text { nilai buku ekuitas }}{\text { nilai pasar ekuitas }}
$$


Variabel dependen pada penelitian ini adalah investasi (investment). Investasi dalam penelitian ini merupakan net capital expenditure dan dihitung selama periode $t$, dirumuskan sebagai berikut:

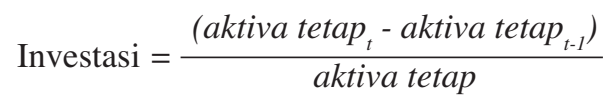

Variabel moderasi pada penelitian ini adalah financial constraints yang diklasifikasikan menjadi dua, yaitu non financially constrained (NFC) dan financially constrained (FC). Dalam penelitian ini untuk mengklasifikasi perusahaan NFC dan FC menggunakan empat tahapan yaitu dengan melihat kebijakan deviden, aliran kas, hutang (leverage), dan kesempatan investasi. Klasifikasi awal didasarkan pada kebijakan deviden. Beberapa penelitian menggunakan rasio pembayaran dividen (Fazzari, Hubbard, dan Petersen, 1988; Vogt, 1994; Kaplan dan Zingales, 1997; Cleary, 1999; Kristianti, 2003; Moyen, 2004; Almeida, Campello, dan Weisbach, 2004; Hermeindito, 2004). Perusahaan dengan dividen rendah masuk kategori FC, sedangkan perusahaan dengan dividen tinggi masuk kategori NFC. Fazzari, Hubbard, dan Petersen (1988) menyatakan bahwa terdapat dua kemungkinan penjelasan mengapa perusahaan membayar dividen rendah. Pertama, perusahaan menghadapi biaya sumber pendanaan eksternal yang mahal karena adanya asimetri informasi sehingga menggunakan sebagian besar laba untuk membiayai investasinya dari pada membayar dividen tinggi. Kedua, perusahaan tidak memperoleh laba yang cukup untuk membayar dividen. Perusahaan yang membayar dividen dimasukkan dalam kategori NFC, sedangkan perusahaan yang tidak membayar dividen dimasukkan dalam kategori FC.

Perusahaan yang masuk kategori FC kemungkinan tidak mampu membayar dividen belum tentu karena tidak mampu membayar, tetapi kemungkinan dana yang dimiliki digunakan untuk kepentingan lain seperti untuk investasi, maka perlu dilakukan klasifikasi yang kedua yaitu dengan melihat aliran kas. Pada klasifikasi kedua sebagaimana digunakan oleh Moyen (2004) perusahaan yang memiliki aliran kas lebih besar dari rata-rata aliran kas seluruh sampel dikategorikan sebagai NFC, sedangkan perusahaan yang memiliki aliran kas lebih kecil dari rata-rata aliran kas seluruh sampel dikategorikan sebagai FC. Perusahaan dengan aliran kas yang besar cenderung tidak akan mengalami kendala dalam pendanaan dan sebaliknya perusahaan dengan aliran kas yang kecil cenderung akan mengalami kendala dalam pendanaan.

Agar mendapatkan hasil klasifikasi perusahaan NFC dan FC yang akurat, maka perusahaan yang masuk kategori financially constrained pada klasifikasi kedua dilanjutkan dengan klasifikasi ketiga yaitu dengan melihat kesempatan investasi yang dimiliki oleh perusahaan. Kesempatan investasi perusahaan dalam hal ini diproksikan dengan rasio book to market sebagaimana 
digunakan oleh Hovakimian dan Titman (2006) dalam mengklasifikasi perusahaan NFC dan FC. Perusahaan masuk kategori NFC apabila rasio book to market perusahaan lebih rendah dari rata-rata rasio book to market seluruh sampel dan perusahaan masuk kategori FC apabila rasio book to market perusahaan lebih tinggi dari rata-rata rasio book to market seluruh sampel. Perusahaan yang memiliki rasio book to market rendah berarti perusahaan tersebut mempunyai nilai buku yang lebih rendah dari nilai pasarnya, dengan kata lain perusahaan tersebut memiliki nilai pasar yang lebih tinggi dari nilai bukunya yang mencerminkan perusahaan NFC. Dengan demikian perusahaan perusahaan NFC akan dengan mudah mendapatkan sumber pendanaan eksternal karena memiliki nilai sekuritas yang tinggi dari nilai bukunya, sehingga investor akan tertarik untuk membeli sekuritas perusahaan tersebut.

Selanjutnya untuk lebih meyakinkan dan memperoleh hasil yang lebih akurat dalam mengklasifikasikan perusahaan NFC dan FC maka perusahaan yang masuk kategori financially constrained pada klasifikasi ketiga dilanjutkan dengan klasifikasi keempat sebagaimana dilakukan oleh Lang, Ofek, dan Stulz (1996); Hovakimian dan Titman (2006) dengan melihat hutang perusahaan. Perusahaan yang memiliki tingkat hutang yang tinggi cenderung sulit untuk mengakses sumber pendanaan eksternal dan sebaliknya perusahaan yang memiliki tingkat hutang yang rendah cenderung lebih mudah untuk mengakses sumber pendanaan eksternal. Untuk itu, dalam penelitian ini perusahaan yang memiliki rasio hutang lebih kecil dari rata-rata rasio hutang seluruh sampel, maka dikategorikan sebagai perusahaan NFC, sedangkan perusahaan yang memiliki rasio hutang lebih tinggi dari rata-rata rasio hutang seluruh sampel maka dikategorikan sebagai perusahaan FC. Dari empat tahapan klasifikasi tersebut, maka untuk lebih jelas dapat dilihat pada gambar 1.

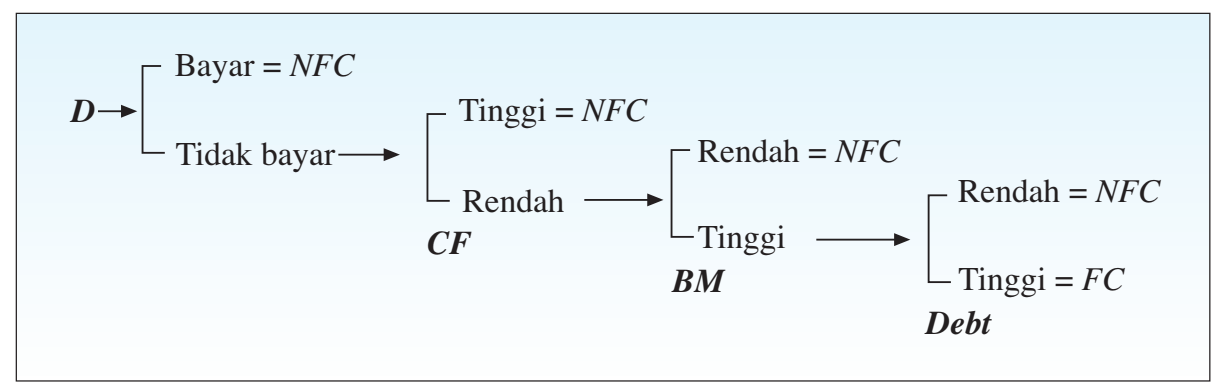

\section{Gambar III.1.}

Klasifikasi perusahaan Financially Constrained dan Non Financially Constrained

Dalam hal ini, D adalah dividen; CF adalah cash flow (aliran kas); BM adalah rasio book to market proksi dari kesempatan investasi; Debt adalah hutang; NFC adalah non financially constrained; dan FC adalah financially constrained. 
Jadi, perusahaan dikategorikan sebagai NFC bila perusahaan tersebut membayar dividen, memiliki aliran kas yang tinggi, book to market yang rendah, dan hutang yang rendah. Sedangkan perusahaan dikategorikan sebagai $F C$ bila perusahaan tersebut tidak membayar dividen, memiliki aliran kas yang rendah, book to market yang tinggi, dan hutang yang tinggi. Penelitian ini juga mengguunakan variabel kontrol yakni hutang (leverage) yang diukur dengan:

$$
\text { DER }=\frac{\text { Total hutang }}{\text { Total ekuitas }}
$$

\section{III.2. Teknik Estimasi}

Model empiris yang diuji dalam paper ini adalah sebagai berikut:

$$
I N V A T_{i t}=\beta_{0}+\beta_{1} C F A T_{i t}+\beta_{2} B M_{i t}+\beta_{3} D_{i t}+\beta_{4} C F A T_{i t} * D_{i t}+\beta_{5} B M_{i t} * D_{i t}+\beta_{6} D E R_{i t}+u_{i t}
$$

Dalam hal ini, INVAT adalah investasi pada pengeluaran modal (capital expenditure) yang dibagi dengan aktiva tetap, merupakan variabel dependen; CFAT adalah aliran kas (cash flow) dibagi dengan aktiva tetap yang merupakan proksi dari likuiditas dan BM (book to market) merupakan proksi dari kesempatan investasi adalah variabel independen; $D$ adalah variabel dummi perusahaan FC dan NFC, 1 adalah perusahaan FC dan 0 adalah perusahaan NFC; CFAT*D adalah interaksi antara CFAT dengan variabel dummy dan $B M^{*} D$ adalah interaksi antara $B M$ dengan variabel dummy, merupakan variabel moderasi; dan DER (debt to equity ratio) merupakan variabel kontrol. Aliran kas dan investasi dibagi dengan aktiva tetap untuk mengkontrol efek perbedaan skala perusahaan. Indeks i menunjukkan perusahaan $i$ dan $t$ adalah periode.

Teknik estimasi yang diterapkan adalah teknik estimasi data panel dengan fixed effect model (FEM) dan common cross-section parameter. Dimungkinkan untuk mempertimbangkan variasi parameter lintas individual perusahaan dan lintas waktu, namun hal tersebut tidak dilakukan dalam penelitian ini.

\section{HASIL DAN ANALISIS}

Berdasarkan kriteria pemilihan sampel yaitu perusahaan non keuangan yang tercatat di Bursa Efek Indonesia (BEI) dan mempublikasikan laporan keuangannya dari tahun 2003- 2007 secara konsisten, diperoleh sampel sebanyak 217 perusahaan non keuangan selama lima tahun dengan jumlah observasi sebanyak 1.085. Dari sampel 217 perusahaan, terdapat 57 perusahaan yang tidak lengkap datanya karena tidak ada data pajak yang ditangguhkan dan 24 perusahaan yang datanya outlier karena memiliki nilai cash flow, book to market, equity, dan investasi 
negatif sehingga dikeluarkan dari sampel. Maka sampel akhir penelitian ini berjumlah 136 perusahaan non keuangan selama lima tahun dengan jumlah observasi 680. Tabel III.1 menunjukkan proses pemilihan sampel.

\begin{tabular}{|c|c|}
\hline $\begin{array}{c}\text { Table III.1 } \\
\text { Proses Pemilihan Sampel }\end{array}$ & \\
\hline Kriteria & Jumlah Perusahaan \\
\hline $\begin{array}{l}\text { 1. Perusahaan non keuangan yang tercatat di BEI dan mempublikasikan } \\
\text { laporan keuangan secara konsisten pada periode 2003-2007 } \\
\text { 2. Dikeluarkan karena data tidak lengkap *) } \\
\text { 3. Dikeluarkan karena data outlier }{ }^{* *} \\
\text { Sampel akhir }\end{array}$ & $\begin{array}{l}217 \\
\frac{(57)}{160}= \\
\frac{(24)}{136}-\end{array}$ \\
\hline
\end{tabular}

Dalam paper ini, untuk mengklasifikasikan perusahaan dikategorikan sebagai FC dan NFC dilihat dari dividen, cash flow, book to market, dan debt. Perusahaan yang dikategorikan sebagai FC bila perusahaan tidak membayar dividen, memiliki cash flow yang lebih rendah dari rata-rata sampel, serta memiliki book to market dan hutang yang lebih tinggi dari rata-rata sampel. Sedangkan perusahaan dikategorikan sebagai NFC bila perusahaan membayar dividen, memiliki cash flow yang lebih tinggi dari rata-rata sampel, serta memiliki book to market dan hutang yang lebih rendah dari rata-rata sampel. Perusahaan FC dan NFC dalam penelitian ini merupakan variabel moderasi yang menggunakan dummy, yaitu: 1 untuk perusahaan $F C$ dan 0 untuk perusahaan NFC. Hasil klasifikasi perusahaan yang dikategorikan sebagai FC dan NFC dapat dilihat pada Gambar III.2.

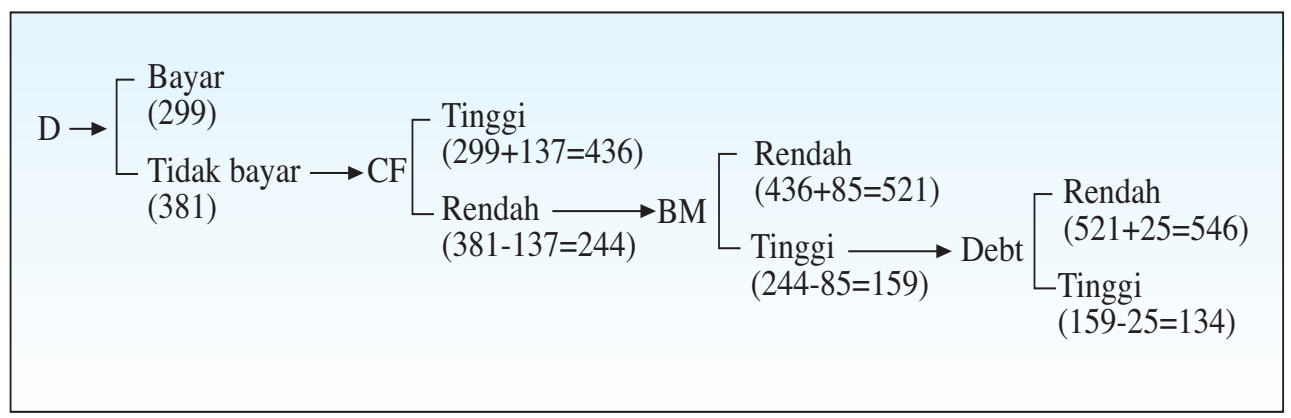
Gambar III.2. Hasil Klasifikasi Perusahaan Financially
Constrained dan Non Financially Constrained 
Gambar ini menunjukkan klasifikasi awal perusahaan dilihat dari status pembayaran dividen; terdapat sejumlah 299 perusahaan yang membayar dividen dan yang tidak membayar dividen sejumlah 381. Pada klasifikasi kedua, perusahaan yang tidak membayar dividen diklasifikasikan lebih lanjut menurut kondisi cash flow-nya; pada tahap ini menunjukkan bahwa perusahaan yang mempunyai cash flow lebih tinggi dari rata-rata sampel bertambah 137 menjadi 436 dan yang lebih kecil dari rata-rata berkurang 137 menjadi 244 perusahaan. Pada klasifikasi ketiga, perusahaan yang masih rendah cash flow-nya dilihat lagi book to marketnya, hasil klasifikasi menunjukkan jumlah perusahaan yang memiliki book to market lebih rendah dari rata-rata sampel bertambah 85 menjadi 521 perusahaan, sedangkan perusahaan yang memiliki book to market lebih tinggi dari rata-rata berkurang 85 menjadi 159 perusahaan. Pada klasifikasi terakhir perusahaan yang masih tinggi book to market-nya dilihat lagi debtnya, hasil klasifikasi menunjukkan bahwa perusahaan yang memiliki debt lebih rendah dari rata-rata sampel bertambah 25 menjadi 546 dan perusahaan yang memiliki debt di atas ratarata sampel berkurang 25 menjadi 134 perusahaan. Dengan demikian perusahaan yang dikategorikan sebagai $F C$ berjumlah 134, sedangkan perusahaan yang dikategorikan sebagai NFC berjumlah 546.

Dari hasil klasifikasi di atas, maka untuk mengetahui perbedaan antara perusahaan FC dan NFC digunakan uji beda dengan independent sample t- test. Hasil dari uji beda perusahaan FC dan NFC dapat dilihat pada tabel III.2.

\begin{tabular}{lcccc}
\multicolumn{5}{c}{ Table III.2 } \\
Hasil Uji Beda Perusahaan Financially Constrained dan Non Financially Constrained \\
\hline Variabel & Mean FC & Mean NFC & Perbedaan Mean & $\mathbf{t}$ value \\
CFAT & 0,8154 & 1,1976 & $-0,3822$ & $-4,867 * * *$ \\
BM & 6,6650 & 3,8180 & 2,8470 & $12,639 * * *$ \\
DER & 0,7097 & 0,4154 & 0,2943 & $12,555 * * *$ \\
\hline
\end{tabular}

Sumber: data diolah

Keterangan :

*** Signifikan pada level $1 \%(2,326)$

CFAT (aliran kas dibagi aktiva tetap), BM (nilai buku ekuitas dibagi nilai pasar ekuitas) dalam kali, DER (total hutang dibagi total ekuitas) dalam persen.

Hasil perhitungan uji beda pada tabel III.2 menunjukkan bahwa terdapat perbedaan ratarata antara perusahaan FC dan NFC pada semua variabel CFAT, BM, dan DER. Tanda koefisien negatif pada CFAT menunjukkan bahwa aliran kas perusahaan NFC lebih tinggi dibanding perusahaan FC, sedangkan varaibel BM dan DER bertanda positif yang berarti bahwa book to market dan hutang perusahaan FC lebih tinggi dari pada perusahaan NFC. 
Hasil estimasi model diberikan pada Tabel III.3. Model ini telah lolos pengujian asumsi klasik (Gujarati, 2003) meliputi uji normalitas, uji autokorelasi, uji multikolinieritas dan uji heteroskedastisitas. Pengujian normalitas data menggunakan uji statistik non parametric Kolmogorov-Smirnov (K-S) dengan nilai 1,313 dan angka signifikansi sebesar 0,064. Ini menunjukkan bahwa data residual terdistribusi normal (Ghozali, 2001).

Pengujian autokorelasi dilakukan dengan menggunakan statistik Durbin Watson (DW) . Dengan jumah observasi 680 dan variabel bebas sebanyak 6, didapatkan nilai dl sebesar 1,707 dan du sebesar 1,831. Hasil uji autokorelasi menunjukkan nilai DW sebesar 1,857 yang terletak antara du dan 4-du, maka pada model tidak terdapat autokorelasi.

Uji multikolinieritas dilakukan dengan melihat nilai VIF, bila nilai VIF mendekati 1 maka persamaan regresi tersebut tidak terjadi multikolinieritas. Hasil uji multikolinieritas menunjukkan bahwa nilai VIF variabel CFAT $(1,069), \operatorname{BM}(1,156)$, dan DER $(1,250)$ adalah mendekati 1, sedangkan nilai VIF variabel $D(5,344), C F A T * D(2,653)$, dan $B M * D(3,939)$ lebih besar dari 1 namun masih dalam batas wajar, sehingga secara keseluruhan dapat dikatakan bahwa tidak ada korelasi antar variabel independen.

Uji asumsi klasik yang terakhir adalah uji heteroskedastisitas yang dilakukan dengan uji Park. Dari hasil uji Park diperoleh hasil signifikansi variabel CFAT $(0,193), \operatorname{BM}(0,864), D(0,481)$, $C F A T * D(0,377), B M * D(0,254)$, dan $\operatorname{DER}(0,866)$ yang berarti lebih besar dari 0.05 , maka di dalam model tidak terdapat heteroskedastisitas yang menjamin parameter yang diperoleh merupakan parameter yang paling efisien.

\begin{tabular}{|c|c|c|c|}
\hline \multicolumn{4}{|c|}{$\begin{array}{c}\text { Table III.3 } \\
\text { Hasil Pengujian Hipotesis }\end{array}$} \\
\hline Variabel Independen & Koefisien & t valu & \\
\hline $\begin{array}{l}\text { Konstanta } \\
\text { CFAT } \\
\text { BM } \\
\text { D } \\
\text { CFAT*D } \\
\text { BM*D }^{*} \text { DER }\end{array}$ & $\begin{array}{c}0,049 \\
0,018 \\
0,001 \\
-0,026 \\
0,011 \\
-0,014 \\
0,027\end{array}$ & $\begin{array}{r}9,102 \\
8,796 \\
1,981 \\
-2,496 \\
1,759 \\
-3,143 \\
3,668\end{array}$ & $\begin{array}{l}* * * \\
* * * \\
* * \\
* * * \\
* * \\
* * * \\
* * *\end{array}$ \\
\hline $\mathrm{R}^{2}$ & & & \\
\hline
\end{tabular}

Sumber: data diolah

Keterangan:

** Signifikan pada level 5\% $(1,645)$

*** Signifikan pada level $1 \%(2,326)$

CFAT (aliran kas dibagi aktiva tetap) adalah proksi dari likuiditas dan BM (nilai buku ekuitas dibagi nilai pasar ekuitas) adalah proksi dari kesempatan investasi merupakan variabel independen; D (variabel dummy, 1 untuk perusahaan financially constrained, 0 untuk perusahaan non financially constrained); CFAT*D (interaksi antara CFAT dengan dummy perusahaan financially constrained) dan BM*D (interaksi antara BM dengan dummy perusahaan non financially constrained) merupakan variabel moderasi; dan DER (total hutang dibagi total ekuitas) adalah variabel kontrol 
Hasil ini menunjukkan bahwa 4 hipotesis yang diajukan dalam paper ini didukung oleh hasil estimasi. Hasil penelitian menunjukkan bahwa hipotesis 1 dan 4 signifikan pada level 1\%, dalam hal ini variabel CFAT memiliki koefisien positif, sedangkan variabel moderasi BM*D yaitu interaksi antara BM dengan dummy perusahaan NFC memiliki koefisien negatif. Untuk hipotesis 2 dan 3, variabel BM dan variabel moderasi CFAT*D yaitu interaksi antara CFAT dengan dummy perusahaan FC memiliki koefisien positif dan signifikan pada level 5\%.

Meski demikian, perlu digarisbawahi bahwa koefisien determinasi $\left(R^{2}\right)$ model relatif kecil sebesar 0,131 yang menunjukkan bahwa 13,1\% variasi keputusan investasi bisa dijelaskan oleh variasi dari keenam variabel independen CFAT, BM, D, CFAT*D, BM*D, dan DER. Sedangkan sisanya $(86,9 \%)$ dijelaskan oleh sebab-sebab yang lain di luar model.

Dengan likuiditas yang tinggi, perusahaan memiliki kesempatan untuk berinvestasi lebih besar pada pengeluaran modal (capital expenditure) yaitu investasi pada aktiva tetap seperti tanah atau properti, bangunan, dan peralatan. Namun demikian, dengan likuiditas perusahaan yang tinggi akan sensitif terjadi konflik keagenan. Menurut teori ini, manajer lebih senang menggunakan modal internal untuk membiayai investasi karena modal internal dapat mengurangi keterlibatan pengawasan dari pemegang saham atau pihak eksternal terhadap keputusan investasi yang dibuat oleh manajer. Manajer cenderung memilih proyek yang lebih sulit dimonitor oleh pihak luar, sehingga memberi keleluasaan yang lebih besar bagi si manajer untuk mengambil keputusan yang menguntungkan dirinya. Manajer juga lebih senang menyimpan free cash flows dari pada membagikannya kepada pemegang saham. Semakin tinggi free cash flows maka semakin besar kebebasan manajer dalam mengontrol sumber daya perusahaan.

Selain itu menurut Myers dan Majluf (1984) bahwa dengan adanya asimetri informasi, maka sumber pendanaan internal lebih murah dibanding pendanaan eksternal seperti hutang, sehingga perusahaan cenderung akan memilih pendanaan internal daripada pendanaan eksternal. Hasil penelitian ini sesuai dengan penelitian Fazzari, Hubbard, dan Petersen (1988); Hoshi, Kashyap, dan Scharfstein (1991); Vogt (1994); Kaplan dan Zingales (1997); Cleary (1999); Agung (2000); Kristianti (2003); Moyen (2004); Almeida, Campello, dan Weisbach (2004); dan Hermeindito (2004). Dengan hasil penelitian ini menunjukkan bahwa terdapat interdependensi antara keputusan investasi dengan keputusan pendanaan.

Keputusan investasi perusahaan sebenarnya lebih dekat kaitannya dengan kesempatan investasi yang dimiliki oleh perusahaan. Hasil hipotesis 2 pada penelitian ini mendukung pernyataan tersebut, dalam hal ini terdapat pengaruh positif kesempatan investasi terhadap keputusan investasi. Penelitian ini sesuai dengan penelitian Fazzari, Hubbard, dan Petersen (1988); Vogt (1994); Kaplan dan Zingales (1997); Cleary (1999); Almeida, Campello, dan 
Weisbach (2004); dan Prasetyantoko (2007). Menurut Gaver dan Gaver (1993), kesempatan investasi merupakan nilai perusahaan yang besarnya tergantung pada pengeluaran-pengeluaran yang ditetapkan manajemen di masa yang akan datang dalam hal ini pilihan-pilihan investasi yang diharapkan akan menghasilkan return yang lebih besar. Jika terdapat kesempatan investasi yang menguntungkan, maka manajer berusaha mengambil peluang-peluang tersebut untuk memaksimalkan kesejahteraan pemegang saham. Semakin besar kesempatan investasi yang menguntungkan, maka investasi yang dilakukan oleh perusahaan akan semakin besar.

Pengaruh likuiditas dan kesempatan investasi terhadap keputusan investasi akan berbeda ketika dimoderasi oleh perusahaan FC dan perusahaan NFC. Hal ini ditunjukkan oleh hasil hipotesis 3 dan 4 . Hasil hipotesis 3 menunjukkan bahwa likuiditas lebih berpengaruh terhadap keputusan investasi pada perusahaan FC dibanding perusahaan NFC. Menurut Fazzari, Hubbart, dan Petersen (1988) disebabkan adanya asimetri informasi pada pendanaan eksternal, sehingga pendanaan eksternal seperti hutang lebih mahal dari pada pendanaan internal yang berakibat perusahaan FC kurang memiliki akses ke sumber pendanaan eksternal. Selain itu perusahaan FC relatif lebih kecil, yang menunjukkan keterbatasan finansial sehingga akan sulit bagi perusahaan mengambil kesempatan investasi yang menguntungkan untuk investasi. Dengan kata lain bahwa perusahaan FC mempunyai nilai perusahaan yang rendah. Dengan demikian, perusahaan FC cenderung lebih sensitif terhadap likuiditas dalam berinvestasi. Hasil penelitian ini sesuai dengan penelitian Fazzari, Hubbart, dan Petersen (1988); Hoshi, Kashyap, dan Scharfstein (1991); Schaller (1993); Almeida, Campello, dan Weisbach (2004); dan Hermeindito (2004).

Sebaliknya, hasil hipotesis 4 menunjukkan bahwa kesempatan investasi lebih berpengaruh terhadap keputusan investasi pada perusahaan NFC dibanding perusahaan FC. Hasil penelitian ini sesuai dengan penelitian Kaplan dan Zingales (1997); Cleary (1999); Kristianti (2003). Menurut Jensen dan Meckling (1976) kebijakan dividen dan kesempatan investasi merupakan mekanisme kontrol manajemen yang dapat bersifat substitusi lebih tergantung penerapannya dari ketersediaan sumber pendanaan internal dari pada sumber pendanaan eksternal melalui kesempatan investasi.

Perusahaan yang memiliki sumber pendanaan internal tinggi dikontrol melalui pembayaran dividen tinggi sehingga perusahaan ini dapat diklasifikasikan sebagai NFC. Dengan demikian perusahaan NFC dapat dengan mudah menyesuaikan sumber pendanaan untuk investasi yang menunjukkan fleksibelitas finansial yang lebih besar dan cenderung mempunyai akses lebih mudah ke pasar modal eksternal. Dengan kata lain perusahaan NFC menunjukkan nilai perusahaan yang tinggi (Bhaddari, 1988; Chan dan Chen, 1991; Fama dan French, 1992). Hal ini berarti bahwa perusahaan NFC lebih sensitif terhadap kesempatan investasi dalam berinvestasi. 


\section{KESIMPULAN}

Dari hasil pengujian hipotesis, maka simpulan dari penelitian ini sebagai berikut:

1. Bahwa likuiditas berpengaruh positif terhadap keputusan investasi. Pengaruh ini menunjukkan bahwa dengan likuiditas yang tinggi, perusahaan memiliki kesempatan untuk berinvestasi lebih besar pada pengeluaran modal (capital expenditure) yaitu investasi pada aktiva tetap seperti tanah atau properti, bangunan, dan peralatan.

2. Bahwa kesempatan investasi berpengaruh positif terhadap keputusan investasi. Jika terdapat kesempatan investasi yang menguntungkan, maka manajer berusaha mengambil peluangpeluang tersebut untuk memaksimalkan kesejahteraan pemegang saham yang berarti juga meningkatkan nilai perusahaan. Dengan demikian, semakin besar kesempatan investasi yang menguntungkan, maka investasi yang dilakukan akan semakin besar.

3. Bahwa likuiditas lebih berpengaruh terhadap keputusan investasi pada perusahaan FC dibanding perusahaan NFC. Hal ini disebabkan adanya asimetri informasi pada pendanaan eksternal, sehingga pendanaan eksternal seperti hutang lebih mahal dari pada pendanaan internal yang berakibat perusahaan FC kurang memiliki akses ke sumber pendanaan eksternal. Hal ini menunjukkan bahwa keputusan investasi perusahaan FC lebih sensitif terhadap likuiditas.

4. Bahwa kesempatan investasi lebih berpengaruh terhadap keputusan investasi pada perusahaan NFC di banding perusahaan FC. Hal ini dikarenakan perusahaan NFC cenderung mempunyai akses lebih mudah ke pasar modal eksternal sehingga dapat dengan mudah menyesuaikan sumber pendanaan untuk investasi yang menunjukkan fleksibelitas finansial yang lebih besar. Hal ini berarti bahwa perusahaan NFC dalam berinvestasi lebih sensitif terhadap kesempatan investasi.

Penelitian ini menunjukkan adanya pengaruh positif likuiditas terhadap keputusan investasi, dengan kata lain terdapat interdepensi antara keputusan pendanaan dalam hal ini likuiditas dengan keputusan investasi pada perusahaan-perusahaan di Indonesia khususnya perusahaan yang menjadi sampel. Keputusan investasi perusahaan lebih dekat hubungannya dengan kesempatan investasi. Hasil penelitian ini mendukung pernyataan tersebut, bahwa terdapat pengaruh positif kesempatan investasi terhadap keputusan investasi pada perusahaanperusahaan di Indonesia khususnya perusahaan yang menjadi sampel.

Ketika pengaruh likuiditas dan kesempatan investasi terhadap keputusan investasi dimasukkan variabel FC dan NFC sebagai variabel moderasi, maka hasil penelitian menunjukkan bahwa likuiditas lebih berpengaruh terhadap keputusan investasi pada perusahaan FC dibanding perusahaan NFC. Implikasinya adalah perusahaan FC cenderung akan menggunakan likuiditas untuk berinvestasi. Hasil penelitian ini juga menunjukkan bahwa kesempatan investasi lebih 
berpengaruh terhadap keputusan investasi pada perusahaan NFC dibanding perusahaan FC. Jika terdapat kesempatan investasi yang menguntungkan, maka perusahaan NFC akan dengan mudah mengambil kesempatan tersebut untuk berinvestasi. Hal ini karena perusahaan NFC lebih mudah dalam mengakses sumber pendanaan eksternal karena memiliki fleksibelitas financial yang lebih besar, lebih berpengalaman, dan lebih lama. Jadi, dalam berinvestasi perusahaan NFC cenderung lebih sensitif terhadap kesempatan investasi.

Perlu digarisbawahi bahwa penelitian ini memiliki keterbatasan yang merupakan ruang pengembangan untuk penelitian lebih lanjut. Hal pertama adalah jumlah sampel yang terbatas, yaitu hanya 136 perusahaan non keuangan selama lima tahun yaitu dari periode 2003-2007 dengan jumlah observasi 680 . Untuk penelitian selanjutnya dapat menambah sampel dengan periode yang lebih panjang. Kedua, banyak sampel yang tidak mengandung nilai akuntansi pajak yang ditangguhkan dalam perhitungan cash flow, sehingga banyak data yang dikeluarkan. Penelitian yang akan datang agar menggunakan proksi cash flow dengan perhitungan lain. Selain itu kecilnya jumlah sampel juga disebabkan terdapat data yang outlier karena memiliki nilai cash flow, book to market, equity, dan investasi negatif. Ketiga, penelitian ini hanya menggunakan dua variabel independen yaitu likuiditas dan kesempatan investasi. Penelitian yang akan datang mungkin perlu menambah variabel independen lain yang relevan seperti hutang, sehingga dapat membandingkan antara sumber pendanaan internal dan sumber pendanaan eksternal yang dimoderasi oleh perusahaan FC dan NFC. Keempat, sampel dipool sehingga satu perusahaan yang masuk kategori perusahaan $F C$ pada tahun ini bisa jadi masuk kategori perusahaan NFC di tahun berikutnya. Seharusnya dibuat Robustness test, dengan cara hold-out sample. Yang dites hanya sampel yang lima tahun atau tiga tahun berturut-turut ada di kategori yang sama. 


\section{DAFTAR PUSTAKA}

Agung, Juda (2000), "Financial Constraint, Firms' Investment and the Channels of Monetary Policy in Indonesia", Apllied Economics, 32: pp. 1637-1646.

Almeida, Heitor, Campello, Murillo, and Weisbach, Michael S. (2004), "The cash Flow Sensitivity of Cash", Journal of Finance, vol. LIX, no. 4: pp. 1777-1804.

Arifin, Zaenal, (2005), "Teori Keuangan dan Pasar Modal", Yogyakarta: Ekonosia.

Brigham, Eugene F. and Ehrhardt, Michael C. (2005), "Financial Management: Theory and Practice" $11^{\text {th }}$ Edition, Thomson, South-Western.

Brigham, E.F., Gapenski, L.C., and Daves, P.R. (1999), "Intermediate Financial Management", $6^{\text {th }}$ Edition, The Dryden Press, Harcourt Brace College Publishers.

Chan, L. K. and Chen, N. (1991), "Structural and Return Characteristics of Small and Large Firms", Journal of Finance, 46: pp. 1467-1484.

Chung, K.H. and Charoenwong, C. (1991), "Investment Options, Assets in Place, and the Risk of Stocks", Financing Management, Autumn: pp. 21-33.

Cleary, Sean (2004), "International Corporate Investment and the Role of Financial Constraint", Saint Mary's University Working Paper.

Cleary, Sean (1999), "The Relationship between Firm Investment and Financial Status", Journal of Finance, vol. LIV no. 2: pp. 673-692.

Fama, Eugene F. (1974), "The Empirical Relationship Between the Dividend and Investment Decisions of Firms", American Economic Review, 76: pp. 323-329.

Fama, Eugene F. and French, Kenneth R. (2000), " Testing Tradeoff and Pecking Order Predictions about Dividents and Debt", The Center for Research in Security Price Working Paper No. 506.

Fama, Eugene F. and French, Kenneth R. (1992), "The Cross-Section of Expected Stock Returns", Journal of Finance, 47: pp. 427-465.

Fazzari, Steven M., Hubbart, Glenn R., and Petersen, Bruce C. (1988), "Financing Constrains and Corporate Investment", Brooking Papers on Economic Activity, 19: pp. 141-195.

Gaver, J.J. and Gaver, K.M. (1993), "Additional Evidence on Association between the Investment Opportunity Set and Corporate Financing, Dividend, and Compensation Policies", Journal of Accounting and Economics, 16: pp. 125-160. 
Geczy, C., Minton, B.A., and Schrand, C. (1997), "Why Firm Use Currency Derivatives", Journal of Finance, 52: pp. 1323-1354.

Ghozali, Imam, (2001), "Aplikasi Analisis Multivariate Dengan Program SPSS", Semarang: BP Undip.

Gujarati, Damodar N. (2003), "Basic Econometric", fourth edition, New York: McGraw-Hill. Hanafi, Mamduh M. dan Halim, Abdul (2005), "Analisis Laporan Keuangan", Edisi kedua, Yogyakarta: UPP AMP YKPN.

Hermeindito (2004), "Asimetri Informasi dan Kontrol Manajemen: Analisis Kepekaan Investasi dan Leverage Terhadap Pemilihan Sumber-sumber Pendanaan", Disertasi Program Doktor, Fakultas Ekonomi dan Bisnis Universitas Gadjah Mada, Tidak dipublikasikan.

Hovakimian, Gayane and Titman, Sheridan, (2006), "Corporate Investment with Financial Constraints: Sensitivity of Investment to Funds from Voluntary Asset Sales", Journal of Money, Credit, and Banking, 38 (2): pp. 357-374.

Hoshi, Takeo, Kashyap, Anil K., and Scharfstein, David, (1986), " Corporate Structure Liquidity and Investment: Evidence from Japanese Panel Data", Quarterly Journal of Economics, 106 : pp. 33-60.

Jensen, Michael C. (1986), "Agency Costs of Free Cash Flow, Corporate Finance, and Takeovers", American Economic Review, 76: pp. 323-329.

Jensen, Michael C. and Meckling, W.H. (1976), "Theory of the Firm: managerial Behavior, Agency Costs, and Ownership Structure", Journal of Financial Economics, vol. 3 no. 4: pp. 305-360.

Kallapur, Sanjay and Trombley, Mark A. (1999), "The Association Between Investment Opportunity Set Proxies and Realized Growth", Journal of Business and Accounting, April/ May: pp. 505-519.

Kaplan, Steven N. and Zingales, Luigi (2000), "Investment-Cash Flow Sensitivities Are Not Valid Measures of Financing Constraints", Quarterly Journal of Economics, May: pp. 707-712.

Kaplan, Steven N. and Zingales, Luigi (1997), "Do Financing Constraints Explain Why Investment is Correlated with Cash Flow?", Quarterly Journal of Economics, 112: pp. 169-215.

Kristianti, Rina A. (2002), "Pengaruh Likuiditas Terhadap Keputusan Investasi Aktiva Tetap pada Perusahaan Yang Dikelompokkan dalam Financially Constraints", Tesis Program Pasca Sarjana (Magister Sains), Fakultas Ekonomi dan Bisnis Universitas Gadjah Mada, Tidak dipublikasikan.

Lang, Larry, Ofek, Eli, and Stulz, Rene M. (1996), "Leverage, Investment, and Firm Growth", Journal of Financial Economics, 40, pp. 3-29.

Modigliani, Franco and Miller, Merton, H. (1958), "The Cost of Capital, Corporation Finance, and the Theory of Investment", American Economics Review, 48: pp. 461-297. 
Moyen, Nathalie (2004), "Investment-Cash Flow Sensitivities: Constrained versus Unconstrained Firms", Journal of Finance, vol. LIX, no. 5: pp. 2061-2092.

Myers, Stewart C. (1984), "The Capital Structure Puzzle", Journal of Finance, 39: pp. 575592.

Myers, Stewart C. and Majluf, Nicholas S. (1984), "Corporate Financing and Investment Decisions when Firms Have Information that Investors Do Non Have", Journal of Financial Economics, 13: pp. 187-221.

Myers, Stewart C. (1977), "Determinant of Corporate Borrowing", Journal of Financial Economics, November: 147-176.

Prasetyantoko, Augustinus, (2007), "Financing Constraints and Firm-Level Investment Following a Financial Crisis in Indonesia", Working Papers on Documents De Travail, Juli: pp. 1-42. Riyanto, Bambang, (1997), "Dasar-dasar Pembelanjaan Perusahaan", edisi 4, Yogyakarta: BPFE. Schaller, Huntley, (1993), "Asymmetric Information, Liquidity Constraints, and Canadian Investment", Canadian Journal of Economics, 26: pp. 552-574.

Smith, Jr. Clifford W. and Watts, Ross L. (1992), "The Investment Opportunity Set and Corporate Financing, Dividend, and Compensation Policies", Journal of Financial Economics, 32: pp. 263-292.

Vogt, S.G. (1994), "The Cash Flow/Investment Relationship: Evidence from U.S. Manufacturing Firm", Financial Management, 23 (2): pp. 3-20. 